\title{
Expression Patterns of 17 $\beta$-Hydroxysteroid Dehydrogenase 14 in Human Tissues
}

\author{
Tove Sivik, Svante Vikingsson, Henrik Gréen and Agneta Jansson
}

\section{Linköping University Post Print}

N.B.: When citing this work, cite the original article.

Original Publication:

Tove Sivik, Svante Vikingsson, Henrik Gréen and Agneta Jansson, Expression Patterns of 17 $\beta$-Hydroxysteroid Dehydrogenase 14 in Human Tissues, 2012, Hormone and Metabolic Research, (44), 13, 949-956.

http://dx.doi.org/10.1055/s-0032-1321815

Copyright: Thieme Publishing / Georg Thieme Verlag http://www.thieme.com/

Postprint available at: Linköping University Electronic Press http://urn.kb.se/resolve?urn=urn:nbn:se:liu:diva-84681 
4

Expression patterns of $17 \beta$ hydroxysteroid dehydrogenase 14 in human tissues

(1)

(1) Tove Sivik$^{1}$, Svante Vikingsson ${ }^{2}$, Henrik Gréen $^{2,3}$, and Agneta Jansson ${ }^{1}$

${ }^{l}$ Division of Oncology, Department of Clinical and Experimental Medicine, Linköping University, Linköping; Sweden. ${ }^{2}$ Division of Drug Research, Clinical Pharmacology, Department of Medical and Health Sciences, Faculty of Health Sciences, Linköping University, Linköping; Sweden, ${ }^{3}$ Division of Gene Technology, Science for Life Laboratory, School of Biotechnology, Royal Institute of Technology, Solna, Sweden.

Corresponding author, to whom reprint requests should be sent: Tove Sivik, Division of Oncology, Department of Clinical and Experimental Medicine, KEF, floor 9 Linköping University S-581 85 Linköping, Sweden. Phone +46 10103 1856; Fax : +46 132228 46; e-mail: tove.sivik@liu.se 8 9 
2 Abstract

3 17ßHSD enzymes catalyse the stereospecific oxidation/reduction at carbon $17 \beta$ of androgens and 4 oestrogens, and are important players in intracrine sex hormone synthesis. The biological relevance of 5 17קHSD14, first named retSDR3, is largely unknown. We generated and validated an antibody 6 targeting the 17ßHSD14 antigen and used this for immunohistochemical evaluation of expression 7 patterns in 33 healthy human tissues. Furthermore, sex steroid conversional activity in HSD17B14 8 over-expressing HEK293 and MCF10A cells was investigated by assessing interconversion products 9 of oestrone, oestradiol, androstenedione, testosterone and dehydroepiandrosterone. 10 Immunohistochemical staining patterns of 17ßHSD14 with the enzyme being primarily expressed in glandular epithelial tissue reveal an enzyme with possible implications in the secretion or conversion of externally derived compounds. A role for $17 \beta$ HSD14 in sex steroid metabolism is supported by the finding that 17HSD14 oxidises both oestradiol and testosterone into less bioactive steroid metabolites oestrone and androstenedione respectively. 


\section{INTRODUCTION}

The gene product of DHRS10, initially named retSDR3, and later $17 \beta$ hydroxysteroid dehydrogenase (17ßHSD) 14, was cloned from a retinal epithelium cDNA-library in the year 2000 [1]. Based on sequence analysis, the protein was determined to be a short-chain dehydrogenase/reductase (SDR), and suggested to be involved in retinol metabolism; however such functional properties could not be shown. In 2006, Lukacik and colleagues further investigated the DHRS10 gene product [2]. Based on structural and functional studies which revealed features of the protein equivalent to those of 17ßHSDs, the DHRS10 gene product was denoted 17ßHSD14 [2].

Using the oxidised or reduced forms of $\mathrm{NAD}(\mathrm{P})(\mathrm{H})$ as hydrogen donors or acceptors, 17ßHSD enzymes catalyse the stereospecific oxidation/reduction at carbon $17 \beta$ of androgens and oestrogens [3]. Upon receptor binding, the 17ß-hydroxy conformation of androgens and estrogens triggers a greater biological response than the corresponding keto-conformation of the steroids [4], and the $17 \beta$ HSD enzymes are thus important mediators in pre-receptor regulation of sex hormone action. Of the 15 types described to date, 14 are found in human, and structurally, all but 17ßHSD type 5 which is an aldo-keto reductase, belong to the SDR-family [5,6]. The 17ßHSD enzymes are a diverse protein family, varying in tissue distribution as well as in substrate preferences. While the major substrates of 17ßHSD enzymes are sex steroids [2,7-11], a few are believed to be dedicated primarily to other substrates, such as fatty acids [12,13], cholesterols [14] bile acids [15] or retinoids [16]. Several of the $17 \beta$ HSDs can work essentially as both reducing and oxidising agents depending on cofactor concentrations and $\mathrm{pH}$, yet in vivo they tend to be unidirectional, and according to experimental data the $17 \beta \mathrm{HSD}$ enzymes are grouped as either oxidative or reductive enzymes based on preferred cofactor utilization under biological conditions. From this classification, human 17ßHSD types 2, 4, 6, 8, 10, 11 and 14 are considered in-vivo oxidative enzymes catalyzing the NAD(P)+-dependent inactivation of oestrogens/androgens whereas types $1,3,5,7,12$ and 15 catalyze the $\mathrm{NAD}(\mathrm{P}) \mathrm{H}-$ dependent reduction, and hence activation, of oestrogens and androgens $[5,6]$.

By catalyzing the final steps in steroid metabolism, the 17ßHSD enzymes, alongside enzymes such as $3 \beta$-hydroxysteroid dehydrogenases, aromatase and sulfotransferases/sulfatases, are thought to be 
important contributors in intracrinology. This element in endocrinology deals with peripheral sex steroid synthesis from adrenally derived precursors, e.g. dehydroepiandrosterone (DHEA), into more potent metabolites such as estradiol (E2) and testosterone (T) [17]. In intracrinology, the biological effect of a sex steroid is the result of local synthesis rather than an outcome mediated by circulating active sex steroids derived from endocrine organs, i. e. the gonads. The local distribution and expression levels of oxidative versus reductive steroidogenic enzymes will eventually affect the finetuning of hormonal profiles in a given target tissue or cell type. In addition to significant roles in normal physiology, many of the enzymes involved in intracrine sex-steroid synthesis have been implicated in steroid-associated pathological conditions such as breast and prostate cancer $[18,19]$.

The current study further elucidates the biological role of 17ßHSD14. An antibody targeting $17 \beta$ HSD14 was prepared and used for determining expression patterns in 33 human tissues. Moreover, the enzymatic potential in converting E2, oestrone (E1), androstenedione (A) and T, was assessed in media from cells transiently over-expressing $H S D 17 B 14$.

\section{MATERIAL AND METHODS}

\subsection{Preparation of polyclonal anti-17ßHSD14 antibody}

The peptide sequence (NH2-)CKASRSTPVDAPDIP(-CONH2) corresponding to amino acids 255 to 269 of human $17 \beta \mathrm{HSD} 14$ with an additional terminal cystein residue for affinity purification purposes, was synthesised and sequenced by AgriSera (Vännäs, Sweden). A breed of New Zeeland white rabbits/French lop received initial subcutaneous injections of $200 \mu \mathrm{g}$ peptide dissolved in a buffer emulsified in Freunds Complete Adjuvant. Three booster injections were administered at 3 months interval; the first including $200 \mu \mathrm{g}$ peptide and the two following $100 \mu \mathrm{g}$. Freunds Incomplete Adjuvant was used with the booster injections. The animals were finally bled one week after the last immunisation and were thereafter sacrificed by injection of an intravenous pentobarbital (Apoteket Stockholm, Sweden). The anti-17ßHSD14 antibody was affinity-purified on a column containing a peptide-coated gel matrix (Ultralink; Thermo Fischer Scientific, Waltham, MA). The preparation of 
the $17 \beta$ HSD14 antibody was performed with permission given by the Swedish animal welfare authority (dnr A112-06). Peptide-neutralisation assay as well as immunoblot analysis of HSD17B14transfected HEK293- and MCF10A cells confirmed antibody specificity.

\subsection{Immunohistochemical evaluation of $17 \beta H S D 14$ expression in various human tissues}

Paraffin-embedded tissue micro array (TMA)-slides composed of totally 33 human tissues from healthy individuals including adrenal gland $(n=3)$, myeloid bone $(n=8)$, breast $(n=60)$, brain $(n=14)$, colon $(n=60)$, eye $(n=3)$, esophagus $(n=8)$, heart $(n=3)$, kidney $(n=8)$, larynx $(n=3)$, liver $(n=8)$, lung $(n=8)$, lymph node $(n=5)$, mesothelium $(n=3)$, nerve $(n=3)$, ovary $(n=8)$, pancreas $n=8)$, parathyroid gland $(n=3)$, pituitary $(n=3)$, prostate $(n=60)$, rectum $(n=5)$, salivary gland $(n=3)$, skeletal muscle $(n=3)$, skin $(n=8)$, duodenum $(n=5)$, spleen $(n=8)$, stomach $(n=8)$, testis $(n=8)$, thymus $(n=8)$, thyroid gland $(n=3)$, tonsil $(n=3)$, uterine cervix $(n=8)$, uterus $(n=3)$, all in $1 \mathrm{~mm}$ diameter cores of $5 \mu \mathrm{m}$ thickness were purchased from Tissue Array Network (Rockville, MD). TMA slides were deparaffinised in xylene and then hydrated in descending concentrations of ethanol. The sections were thereafter treated in a decloaking buffer (Biocare Medical, Concord, CA) in a decloaking chamber to retrieve antigenicity. The temperature was allowed to reach $120^{\circ} \mathrm{C}$ at which the heat was turned off. To reduce non-specific staining, sections were immersed in phosphate-buffered saline (PBS) supplemented with $0.1 \%$ bovine serum albumin (BSA) and then incubated with a commercial protein blocking solution (Spring Bioscience, Pleasanton, CA) for 10 minutes. The tissue sections were incubated with the in-house polyclonal rabbit anti-human 17ßHSD14 antibody diluted to 1:1200 in antibody diluent (DakoCytomation, Glostrup, Denmark) at $4^{\circ} \mathrm{C}$ over night. After a washing step in PBS/BSA, sections were incubated with EnVision horseradish peroxidate-conjugated anti-rabbit polymer (DakoCytomation) for 25 minutes. The immune reaction was visualised by incubating the samples in a solution containing 3,3-diaminobenzidine chromogen supplemented with hydrogen peroxide for eight minutes. Sections were briefly counterstained with hematoxylin, dehydrated in ascending concentrations of ethanol and finally mounted. A test for antibody specificity was performed by peptide neutralising assay. Pre-incubation of antibody and 17ßHSD14-peptide was done 
1 for two hours in RT with peptide $\left(10^{-6} \mathrm{M}\right)$ and 17ßHSD14 antibody (1:600) at a molar ratio of 100:1 in

2 tris-buffered saline with tween (TBST) without blocking reagent. The pre-incubation solution was

3 mixed with an equal volume of TBST supplemented with blocking solution and added to the TMA

4 tissue for overnight incubation. The TMAs were investigated microscopically using a Leica LB30T

5 microscope (Leica Microsystems, Wetzlar, Germany) by two independent investigators blinded to

6 clinical data (T.S and A.J), and the findings were confirmed by a pathologist (HO). Representative

7 slides were photographed using an Olympus SC20 digital camera (Olympus Europe GmbH, Hamburg,

8 Germany).

\subsection{Transient transfection of cultured cells with HSD17B14}

HEK293 cells (American Type Culture Collection, ATCC, Manassas, VA; ATCC number CRL-1573) were seeded at 16000 cells $/ \mathrm{cm}^{2}$ in 24 -well plates in $0.5 \mathrm{ml} /$ well OPTIMEM phenol-red free OptiMEM medium (Invitrogen, Carlsbad CA) supplemented with 4\% charcoal-treated serum (CTS) (Invitrogen). MCF10A cells (ATCC number CRL-10781), were seeded at at $16000 \mathrm{cells} / \mathrm{cm}^{2}$ in 24well plates in $0.5 \mathrm{ml} /$ well in ATCC complete growth medium supplemented with $20 \mathrm{ng} / \mathrm{ml}$ epidermal growth factor, $100 \mathrm{ng} / \mathrm{ml}$ cholera toxin, $0.01 \mathrm{mg} / \mathrm{ml}$ insulin and $500 \mathrm{ng} / \mathrm{ml}$ hydrocortisone. All cells were cultured at $37^{\circ} \mathrm{C}$ in $5 \% \mathrm{CO}_{2}$. Twenty-four hours after seeding, the cells were transfected with a commercial HSD17B14-plasmid (Origene, Rockville, MD, USA), using Xtremegene transfection reagent (Roche Diagnostics, Indianapolis, IN). Mock-transfected cells were incubated with the same amount of a vector missing the HSD17B14 insert. (Roche Diagnostics, Indianapolis, IN). Transfection efficiency was evaluated by measuring 17ßHSD14 expression in transfected cells with western blot.

\subsection{Western blot}

$30 \mu \mathrm{g}$ of protein from lysates of non-transfected, mock-transfected cells was subjected to electrophoretic separation on 5-15\% SDS-PAGE gels (BioRad, Hercules, CA) at $200 \mathrm{~V}$ for 30 minutes. The proteins were then blotted onto a PVDF-membranes for 60 minutes at $100 \mathrm{~V}$. 
Electrophoresis and western blotting was performed using the Criterion precast gel System (BioRad). The membranes with blotted proteins were blocked in TBS-tween (TBST) supplemented with $5 \%$ non-fat skimmed milk (BioRad) for 60 minutes on a shaker after which it was incubated with an inhouse polyclonal rabbit anti-17ßHSD14 antibody, diluted in blocking solution to $1: 1000$ at $4^{\circ} \mathrm{C}$ over night. The membranes were then washed three times with TBST solution and incubated at ambient temperature for 60 minutes with a secondary HRP-conjugated anti-rabbit IgG (DakoCytomation), diluted to 1:2000 in blocking solution. The blot was washed three times in TBST and bound antibodies were detected using ECL plus detection reagents (Amersham, Arlington Heights, IL). Results were visualised using LAS1000 CCD-camera detection system (FujiFilm, Tokyo, Japan). A monoclonal anti human $\beta$-aktin antibody (Cell Signaling, Beverly, MA) was used to control for equal loading.

\subsection{Assessment of enzymatic conversion of tritiated substrates in cultured cells over-expressing}

\section{HSD17B14}

Twenty four hours after transfection, cell culture media was aspired and replaced by Opti-MEM I with $4 \%$ CTS supplemented with $10 \mathrm{nM}$ of tritiated sex steroids; androst-4-ene-3, [1,2,6,7- $\left.{ }^{3} \mathrm{H}(\mathrm{N})\right]-, 17-$ Dione (98.1 Ci/mmol; range 70-110 Ci), oestradiol, [2,4,6,7- $\left.{ }^{3} \mathrm{H}(\mathrm{N})\right]-(70 \mathrm{Ci} / \mathrm{mmol}$; range $70-115 \mathrm{Ci})$, oestrone, $\left[2,4,6,7-{ }^{3} \mathrm{H}(\mathrm{N})\right]-(89.3 \mathrm{Ci} / \mathrm{mmol}$; range $50-100 \mathrm{Ci})$, testosterone, $\left[1,2,6,7-{ }^{3} \mathrm{H}(\mathrm{N})\right]-(70$ $\mathrm{Ci} / \mathrm{mmol}$; range $70-105 \mathrm{Ci})$ and dehydroepiandrosterone, $\left[1,2,6,7-{ }^{3} \mathrm{H}(\mathrm{N})\right]-(50 \mathrm{Ci} / \mathrm{mmol}$; range $60-100$ Ci) (Perkin Elmer, Waltham, MA. Cell culture media was collected at 0, 4, 8, 24, 48 and 72 hours, and stored at $-70^{\circ} \mathrm{C}$ until analysis. Experiments were run in duplicates and the whole procedure was repeated at least three times. Media samples with tritiated sex steroid metabolites were incubated without cells in order to monitor spontaneous steroid degradation within the given time interval.

\subsection{Sample preparation and HPLC-analysis of steroid interconversion}

The procedure for sample preparation, separation and detection of sex steroid interconversion product has been published elsewhere [20] and was used with minor modifications. Briefly, cell culture media 
samples containing tritiated steroid interconversion products were precipitated using cold zinc sulphate solution (10\%) and $1 \mathrm{M}$ sodium hydroxide solution. After centrifugation, supernatants were transferred to injection vials for analysis. Samples were injected onto a Beckman Coulter Ultrasphere ODS column, $250 \times 4.6 \mathrm{~mm}, 5 \mu \mathrm{m}$ (Bromma, Sweden), maintained at $40^{\circ} \mathrm{C}$. The retention time for androstenediol was experimentally determined using UV detection of unlabelled substrate. During the run the autosampler was kept at $15^{\circ} \mathrm{C}$. Between two and 14 minutes scintillation fluid (Ultima-Flo, Perkin Elmer) was mixed with the column eluent in a 2:1 ratio enabling radiochemical detection of the tritium labeled steroids.

\section{RESULTS}

\subsection{Antibody specificity}

Immunoblot analysis of lysates from HEK293 and MCF10A cells transiently transfected with $H S D 17 B 14$ revealed a single band at expected size $28 \mathrm{kDa}$. Weak or no bands were present in mocktransfected or non-transfected cells (Fig. 1). When neutralized by a 17ßHSD14-peptide, immunopositivity in liver was not evident (Fig. 3).

\subsection{7ßHSD14 distribution in human tissues}

In order to evaluate the localisation of $17 \beta \mathrm{HSD} 14$ on a sub-tissue level we generated an antibody towards the antigen and used this for immunohistochemical analysis of the protein in 33 human tissues (Table 1). In specimens representing female reproductive organs (Fig. 2 A-D), uterus showed weak to moderate cytoplasmic immunoreactivity in the secretory glandular epithelium of the endometrium, whereas peritubular area, comprised of mainly smooth muscle, was unstained. Ovarian specimens showed immunoreactivity in granulosa cells of dominant follicles as well as in atretic corpus luteum. Breast specimens showed moderate to strong staining of 17ßHSD14 in the cytoplasms of ductal epithelial cells. Periductal stromal areas were unstained. In male reproductive organs (Fig. 2 E and F), 
prostate samples showed negative to weak immunoreactivity. In testis, immunoreactivity was seen in most of the seminiferous epithelium as well as in peritubular areas harbouring Leydig cells. 17ßHSD14 was highly expressed in kidney, with samples showing strong immunoreactivity in glandular cells of both proximal and distal tubules while cells of Bowman's capsule and endothelial cells of glomeruli remained unstained (Fig. 3 A). In retina, 17ßHSD14 was present in cytoplasmic projections of the plexiform layers whereas nuclear layers were negative, with an exception for the inner nuclear layer, where staining was prominent in some nuclei (Fig. 3 B). 17ßHSD14 expression was also evident in the gastrointestinal (GI) area (Fig. 3 C-F); in stomach samples, staining was relatively strong in upper mucosal areas whereas underlying stroma was unstained. Most 17ßHSD14 appeared to be located cytoplasmically although some nuclear staining was evident. In duodenal specimens, staining was weak to moderate throughout the mucosal layer. In colon and rectal samples, the presence of $17 \beta \mathrm{HSD} 14$ was especially marked at the absorptive edges of the mucosa facing the GIlumen. Both enterocytes and goblet cells of the mucosal crypts stained, and although staining was mostly cytoplasmic, as in the stomach, some nuclear staining was evident. In the deeper layers of the mucosa, staining diminished gradually and was virtually absent below the inner muscular layer. When tissues of both sexes were available, no apparent differences in staining intensities or distribution patterns were seen when taking gender of tissue donor into account.

\subsection{Steroid interconversion}

In order to assess steroid conversion by 17ßHSD14, HEK293 cells were transfected with an expression vector containing the HSD17B14 insert. Transfected cells were thereafter exposed to radiolabelled steroids, and generated tritiated products were separated by HPLC and detected by $\beta$ scintillation. The rate of steroid interconversion of oestrone/oestradiol and androstenedione/testosterone was obtained by integrating generated peak areas and computing ratios of E1/E2 and A/T. HSD17B14 transfected cells oxidised oestradiol and testosterone to oestrone and androstenedione respectively with net efficiencies of approximately $15 \%$ for the oestradiol to oestrone reaction and $8 \%$ for the testosterone to androstenedione conversion compared with mock-transfected 
cells. No reduction of E1, A or DHEA exceeding that of mock-transfected cells was seen for HSD17B14-transfected cells (Fig. 4 A-E).

\section{DISCUSSION}

To date, 15 isoenzymes of the 17ßHSD family have been described [5,6]. The extent to which individual enzymes of this family have been studied varies. The relevance of the $17 \beta$ HSD14 protein in normal physiology has not been addressed, although we have previously shown tumoural expression of both $H S D 17 B 14$ mRNA and the $17 \beta \mathrm{HSD} 14$ protein to be of importance in breast cancer, both for predicting prognosis [21] and in predicting tamoxifen treatment response [22]. In both cases, 17ßHSD14 appears to be a factor predicting good clinical outcome in breast cancer; however, functional mechanisms underlying this remain elusive. The current study was initiated in order to learn more of the normal physiology of the $17 \beta \mathrm{HSD} 14$ protein. An antibody targeting the $17 \beta \mathrm{HSD} 14$ antigen was rasied and used for immunohistochemical analysis of healthy human tissues. Furthermore, enzymatic properties of the protein in intact cells were assessed. Overall, distribution patterns and activity measurements of $17 \beta$ HSD14 support the theory of the enzyme being an actor in intracrine sex steroid interconversion.

17ßHSD14 was first cloned from a retinal cDNA library in 2000 by Haeseleer and Palczewski [1]. Based on amino acid sequence, the enzyme was predicted to utilize NADPH as a cofactor, which would render the enzyme reductive. However, using recombinant protein expressed in insect cells, the authors could not detect transfer of ${ }^{3} \mathrm{H}$ from $\left[{ }^{3} \mathrm{H}\right] \mathrm{NADPH}$ to any of the steroid substrates tested. Lukacik et al re-evaluated the same gene product in 2006 and also solved the crystal structure of 17ßHSD14. The purified recombinant enzyme was screened against a compound library and was found to convert NAD+ to NADH in the presence of oestradiol, testosterone and 5-androstenediol. Oestradiol oxidation to oestrone was shown in a cell based system overexpressing HSD17B14 [2]. In the current study, we utilized a similar cell based system and found significantly higher oxidation of both oestradiol and testosterone into oestrone and androstenedione respectively for transient HSD17B14 overexpression compared with mock-transfected cells. The relevance of 17ßHSD14 as a steroid-converting enzyme was strengthened by the immunohistochemical findings, which showed 
presence of $17 \beta \mathrm{HSD} 14$ in several steroidogenic tissues including uterus, testis and breast. Among female and male reproductive tissues, 17ßHSD14 was most strongly expressed in uterus and testis respectively, staining endometrial glands as well as male germ cells and Leydig cells, where $17 \beta$ HSD14 may participate in the fine-tuning of the levels of bioactive sex hormones which is crucial for the homeostasis in these tissues. $17 \beta \mathrm{HSD} 14$ was not expressed in prostate tissue. Among a large number of normal breast samples analysed, 17ßHSD14 was highly expressed in the majority. It has been suggested that the predominant enzymatic direction in normal breast is oxidative, favouring E2 to E1 conversion, whereas tumour progression is associated with a shift towards a reductive environment, and these changes have been shown to concur with changes in local protein expression of steroidogenic enzymes from a dominance of oxidative enzymes such as 17ßHSD2, towards increased expression of reducing enzymes, e.g. 17ßHSD1 [23-25].

17ßHSD14 was expressed throughout the gastrointestinal tract with most prominent staining seen in stomach as well as in colonic and rectal samples. In colon and rectal samples, immunoreactivity of enterocytes and goblet cells of mucosal crypts was prominent in the outer absorptive border facing the lumen, whereas positivity towards the deeper situated glands gradually diminished. The same pattern, although not as marked, was seen in duodenal samples. Based on expression patterns in mucosal layers of the colon and rectum, which resemble those published regarding other oxidizing 17ßHSD enzymes, e.g. type 2 and 4 in colon [26,27], it is suggestive that 17ßHSD14 has a role in protecting tissues from exposure to excess reduced steroidal agents such as ingested or bacterially derived oestradiol. As proposed by English et al, the primary enzymatic activity in colonic tissue is oxidative, favouring the inactivation of potent sex steroids [27].

The kidney harbours several steroidogenic enzymes [28-30]. The exact significance of steroid metabolism in renal cells has not been extensively studied, although observed gender differences in e.g. blood pressure response to salt stimuli and the tendency to form urinary stones suggests involvement of sex steroids in the regulation of tubular reabsorption [28]. In our study, 17ßHSD14 positivity in kidney was intense and specific, present in epithelial cells of proximal and distal tubules whereas renal corpuscles were negative. Specific immunopositivity for 17ßHSD14 and other 17ßHSD 
enzymes such as $17 \beta$ HSD5 in sites for selective ion and water transport in the kidney could possibly suggest a role for $17 \beta \mathrm{HSD}$ enzymes in normal reabsorption physiology [28,31].

The $H S D 17 B 14$ gene product was first cloned from a retinal cDNA-library and was also found to be highly expressed therein [1]. We found 17ßHSD14 immunoreactivity in cytoplasmic projections of the plexiform layers of the retina, whereas nuclear layers were negative, with an exception for the inner nuclear layer, where staining was prominent in specific nuclei, most likely belonging to amacrine cells. Interestingly, the inner nuclear layer of the retinal epithelium has been shown to harbour the highest density of steroidogenic enzymes in rat retina [32]. The presence of 17ßHSD14 in retina could be related to a role in steroid metabolism, but it could also be related to a possible role in retinoid metabolism. 17ßHSD enzymes share homology with retinol dehydrogenase enzymes, and some 17ßHSD enzymes have been shown to metabolise retinoids [16,33,34]. As recently shown by Haller et al., the exchange of a single amino acid in the 17ßHSD1 enzyme makes the enzyme efficiently reducing all-trans-retinal to its alcohol [35].

Although conversion data support a role for $17 \beta \mathrm{HSD} 14$ in sex steroid metabolism, the conversion rates of these reactions are relatively low, with approximately $8-15 \%$ of the added hydroxysteroids being oxidized after 72 hours. In comparison, and as a methodological control, using the same transfection system, we transiently over-expressed $H S D 17 B 2$ and found $100 \%$ of added oestradiol to be oxidised to oestrone within less than 24 hours. The low efficiency of $17 \beta$ HSD14 in oxidising hydroxysteroids could possibly suggest that the enzyme in addition operates on other, yet unknown substrates. A role for 17ßHSD14 in inflammatory responses is proposed by a recent interesting publication by Saijo et al., in which 17ßHSD14 is shown to act immunomodulatory by reducing DHEA into androstenediol, which in turn is shown to be a significant inducer of anti-inflammatory responses mediated by ER $\beta$ in the central nervous system [36]. When adding DHEA as a substrate to transiently $H S D 17 B 14$ over-expressing MCF10A cells, we detected no reduction exceeding that of mock-transfected cells within 72 hours using our HPLC-based system. The reason for this apparent discrepancy remains elusive, and the suggestion that $17 \beta \mathrm{HSD} 14$ would potently act as a reductive enzyme as shown by Saijo et al., is intriguing as neither we, nor Lukacik et al., could detect reductive 
activity when adding ketosteroids such as E1 or A as substrates to purified enzyme [2] or cells overexpressing $H S D 17 B 14$. It has been shown that oxidation or reduction reactions catalysed by $17 \beta H S D$ enzymes are essentially reversible reactions, however, in intact cells these enzymes cause equilibrium, favouring either the 17ß-hydroxy conformation or the 17-keto conformation of the sex steroid, and the enzymes are thus classified as either reductive or oxidative [37]. Sherbet et al., have shown that whereas the E2/E1 ratio in cell culture media of cells expressing $H S D 17 B 1$ could be altered by glucose deprivation which causes changes in the NADPH/NADP+ ratio and thus alters the preference from $\mathrm{E} 1$ to E2 as a substrate, the preference of $H S D 17 B 2$ for E2 oxidation was not affected by changes in the NAD+/NADH gradient [3]. The influence on the enzymatic properties of $17 \beta$ HSD14 of factors that could affect cofactor availability, such as prolonged incubation times with subsequent changes in cell density and $\mathrm{pH}$, have not been investigated, hence there remains a possibility that differences in cell culture conditions could be the cause of the dissimilar results. The discrepancy could also stem from the fact that a different cell line is used or even the means of analysis used which differs between our studies. Whereas Saijo et al used non-labelled steroids which after extraction from cell culture media were derivatised and then separated/analysed with gas chromatography, we used radiolabelled steroids which were separated via reversed phase HPLC and detected by an on-line scintillographer. Further studies on the topic of $17 \beta$ HSD14 substrate preference are warranted.

In conclusion, the $17 \beta \mathrm{HSD} 14$ enzyme is expressed in several classical steroidogenic tissues such as breast, ovary and testis which supports the theory of 17ßHSD14 being an actor in intracrine sex steroid interconversion. This theory is further strengthened by the finding that $17 \beta$ HSD14 oxidises both oestradiol and testosterone in intact cells. Immunohistochemical staining patterns of 17BHSD14 with the enzyme being primarily expressed in glandular epithelial cells, may implicate a role for the enzyme in modulating the levels of secreted sex steroids, either endogenous or externally derived. 


\section{REFERENCES}

1. Haeseleer F, Palczewski K. Short-chain dehydrogenases/reductases in retina. Methods in enzymology 2000;316:372-383

2. Lukacik P, Keller B, Bunkoczi G, Kavanagh KL, Lee WH, Adamski J, Oppermann U. Structural and biochemical characterization of human orphan DHRS10 reveals a novel cytosolic enzyme with steroid dehydrogenase activity. The Biochemical journal 2007;402:419-427

3. Sherbet DP, Guryev OL, Papari-Zareei M, Mizrachi D, Rambally S, Akbar S, Auchus RJ. Biochemical factors governing the steady-state estrone/estradiol ratios catalyzed by human 17beta-hydroxysteroid dehydrogenases types 1 and 2 in HEK-293 cells. Endocrinology 2009;150:4154-4162

4. Sonneveld E, Riteco JAC, Jansen HJ, Pieterse B, Brouwer A, Schoonen WG, van der Burg B. Comparison of in vitro and in vivo screening models for androgenic and estrogenic activities. Toxicological Sciences 2006;89:173-187

5. Day JM, Tutill HJ, Purohit A, Reed MJ. Design and validation of specific inhibitors of $17 \beta-$ hydroxysteroid dehydrogenases for therapeutic application in breast and prostate cancer, and in endometriosis. Endocrine-Related Cancer 2008;15:665-692

6. Luu-The $V$, Bélanger A, Labrie F. Androgen biosynthetic pathways in the human prostate. Best Practice and Research: Clinical Endocrinology and Metabolism 2008;22:207-221

7. Brereton P, Suzuki T, Sasano H, Li K, Duarte C, Obeyesekere V, Haeseleer F, Palczewski K, Smith I, Komesaroff $\mathrm{P}$, Krozowski Z. Pan1b (17BHSD11)-enzymatic activity and distribution in the lung. Molecular and Cellular Endocrinology 2001;171:111-117

8. Geissler WM, Davis DL, Wu L, Bradshaw KD, Patel S, Mendonca BB, Elliston KO, Wilson JD, Russell DW, Andersson S. MALE PSEUDOHERMAPHRODITISM CAUSED BY MUTATIONS OF TESTICULAR 17-BETA-HYDROXYSTEROID DEHYDROGENASE-3. Nature Genetics 1994;7:34-39

9. Akinola LA, Poutanen M, Peltoketo H, Vihko R, Vihko P. Characterization of rat $17 \beta$ hydroxysteroid dehydrogenase type 1 gene and mRNA transcripts. Gene 1998;208:229-238

10. Wu L, Einstein M, Geissler WM, Chan HK, Elliston KO, Andersson S. EXPRESSION CLONING AND CHARACTERIZATION OF HUMAN 17-BETA-HYDROXYSTEROID DEHYDROGENASE TYPE-2, A MICROSOMAL-ENZYME POSSESSING 20-ALPHA-HYDROXYSTEROID DEHYDROGENASEACTIVITY. Journal of Biological Chemistry 1993;268:12964-12969

11. Biswas MG, Russell DW. Expression cloning and characterization of oxidative 17beta- and 3alpha-hydroxysteroid dehydrogenases from rat and human prostate. J Biol Chem 1997;272:15959-15966

12. Markus M, Husen B, Leenders F, Seedorf U, Jungblut PW, Hall PH, Adamski J. Peroxisomes contain an enzyme with 17 beta-estradiol dehydrogenase, fatty acid hydratase/dehydrogenase, and sterol carrier activity. Ann N Y Acad Sci 1996;804:691-693

13. Moon YA, Horton JD. Identification of two mammalian reductases involved in the two-carbon fatty acyl elongation cascade. J Biol Chem 2003;278:7335-7343

14. Krazeisen A, Breitling R, Imai K, Fritz S, Moller G, Adamski J. Determination of CDNA, gene structure and chromosomal localization of the novel human 17beta-hydroxysteroid dehydrogenase type 7(1). FEBS Lett 1999;460:373-379

15. Shafqat N, Marschall HU, Filling C, Nordling E, Wu XQ, Bjork L, Thyberg J, Martensson E, Salim $S$, Jornvall $H$, Oppermann U. Expanded substrate screenings of human and Drosophila type 10 17beta-hydroxysteroid dehydrogenases (HSDs) reveal multiple specificities in bile acid and steroid hormone metabolism: characterization of multifunctional 3alpha/7alpha/7beta/17beta/20beta/21-HSD. Biochem J 2003;376:49-60

16. Zhang M, Chen W, Smith SM, Napoli JL. Molecular characterization of a mouse short chain dehydrogenase/reductase active with all-trans-retinol in intact cells, mRDH1. J Biol Chem 2001;276:44083-44090 
17. Labrie F, Belanger A, Simard J, LuuThe V, Labrie C. DHEA and peripheral androgen and estrogen formation: Intracrinology. In: Bellino FL, Daynes RA, Hornsby PJ, Lavrin DH, Nestler JE eds, Dehydroepiandrosterone. New York: New York Acad Sciences; 1995:16-28

18. Oduwole OO, Li Y, Isomaa VV, Mäntyniemi A, Pulkka AE, Soini Y, Vihko PT. 17ßHydroxysteroid dehydrogenase type 1 is an independent prognostic marker in breast cancer. Cancer Research 2004;64:7604-7609

19. Gunnarsson C, Jerevall PL, Hammar K, Olsson B, Nordenskjöld B, Jansson A, Stål O. Amplification of HSD17B1 has prognostic significance in postmenopausal breast cancer. Breast Cancer Research and Treatment 2008;108:35-41

20. Sivik $\mathrm{T}$, Vikingsson $\mathrm{S}$, Gréen $\mathrm{H}$, Jansson $\mathrm{A}$. A validated and rapid high-performance liquid chromatography method for the quantification of conversion of radio-labelled sex steroids. Horm Mol Biol Clin Invest 2010;3:375-381

21. Jansson AK, Gunnarsson C, Cohen M, Sivik T, Stål O. 17ß-hydroxysteroid dehydrogenase 14 affects estradiol levels in breast cancer cells and is a prognostic marker in estrogen receptorpositive breast cancer. Cancer Research 2006;66:11471-11477

22. Sivik T, Gunnarsson C, Fornander T, Nordenskjold B, Skoog L, Stal O, Jansson A. 17betahydroxysteroid dehydrogenase type 14 is a predictive marker for tamoxifen response in oestrogen receptor positive breast cancer. PLoS One 2012;7:e40568

23. Sasano H, Frost AR, Saitoh R, Harada N, Poutanen M, Vihko R, Bulun SE, Silverberg SG, Nagura $\mathrm{H}$. Aromatase and $17 \beta$-hydroxysteroid dehydrogenase type 1 in human breast carcinoma. Journal of Clinical Endocrinology and Metabolism 1996;81:4042-4046

24. Speirs V, Walton DS, Hall MC, Atkin SL. In vivo and in vitro expression of steroid-converting enzymes in human breast tumours: associations with interleukin-6. Br J Cancer 1999;81:690695

25. Speirs V, Green AR, Atkin SL. Activity and gene expression of 17beta-hydroxysteroid dehydrogenase type I in primary cultures of epithelial and stromal cells derived from normal and tumourous human breast tissue: the role of IL-8. J Steroid Biochem Mol Biol 1998;67:267-274

26. Sano T, Hirasawa G, Takeyama J, Darnel AD, Suzuki T, Moriya T, Kato K, Sekine H, Ohara S, Shimosegawa T, Nakamura J, Yoshihama M, Harada N, Sasano H. 17 beta-Hydroxysteroid dehydrogenase type 2 expression and enzyme activity in the human gastrointestinal tract. Clin Sci (Lond) 2001;101:485-491

27. English MA, Hughes SV, Kane KF, Langman MJ, Stewart PM, Hewison M. Oestrogen inactivation in the colon: analysis of the expression and regulation of 17beta-hydroxysteroid dehydrogenase isozymes in normal colon and colonic cancer. Br J Cancer 2000;83:550-558

28. Azzarello J, Fung KM, Lin HK. Tissue distribution of human AKR1C3 and rat homolog in the adult genitourinary system. J Histochem Cytochem 2008;56:853-861

29. Sakurai N, Miki Y, Suzuki T, Watanabe K, Narita T, Ando K, Yung TMC, Aoki D, Sasano H, Handa H. Systemic distribution and tissue localizations of human 17beta-hydroxysteroid dehydrogenase type 12. Journal of Steroid Biochemistry and Molecular Biology 2006;99:174181

30. Chai Z, Brereton P, Suzuki T, Sasano H, Obeyesekere V, Escher G, Saffery R, Fuller P, Enriquez C, Krozowski Z. 17ß-hydroxysteroid dehydrogenase type XI localizes to human steroidogenic cells. Endocrinology 2003;144:2084-2091

31. Azzarello JT, Lin HK, Gherezghiher A, Zakharov V, Yu Z, Kropp BP, Culkin DJ, Penning TM, Fung KM. Expression of AKR1C3 in renal cell carcinoma, papillary urothelial carcinoma, and Wilms' tumor. Int J Clin Exp Pathol 2009;3:147-155

32. Cascio C, Russo D, Drago G, Galizzi G, Passantino R, Guarneri R, Guarneri P. 17beta-estradiol synthesis in the adult male rat retina. Exp Eye Res 2007;85:166-172

33. Baker ME. Evolution of 17beta-hydroxysteroid dehydrogenases and their role in androgen, estrogen and retinoid action. Mol Cell Endocrinol 2001;171:211-215 
34. Biswas MG, Russell DW. Expression cloning and characterization of oxidative 17 beta- and 3 alpha-hydroxysteroid dehydrogenases from rat and human prostate. Journal of Biological Chemistry 1997;272:15959-15966

35. Haller F, Moman E, Hartmann RW, Adamski J, Mindnich R. Molecular framework of steroid/retinoid discrimination in 17beta-hydroxysteroid dehydrogenase type 1 and photoreceptor-associated retinol dehydrogenase. J Mol Biol 2010;399:255-267

36. Saijo K, Collier JG, Li AC, Katzenellenbogen JA, Glass CK. An ADIOL-ERbeta-CtBP transrepression pathway negatively regulates microglia-mediated inflammation. Cell 2011;145:584-595

37. Khan N, Sharma KK, Andersson S, Auchus RJ. Human 17beta-hydroxysteroid dehydrogenases types 1,2 , and 3 catalyze bi-directional equilibrium reactions, rather than unidirectional metabolism, in HEK-293 cells. Arch Biochem Biophys 2004;429:50-59

\section{LEGENDS}

\section{Figure 1}

Immunoblot analysis of lysates from HEK293 (A) and MCF10A (B) cells over-expressing HSD17B14. A single band at $28 \mathrm{kDa}$ corresponding to $17 \beta \mathrm{HSD} 14$ is seen in lane 2 of both blots. The band is not present in lanes 3 and 4 (row 2) representing mock-transfected and untransfected cells respectively. $\beta$-actin (upper row), at $45 \mathrm{kDa}$ is used to control for equal loading.

\section{Figure 2}

17ßHSD14 immunolocalisation in reproductive tissue; A, uterus, B, ovary, C, uterus, D, breast, E, testis and F, prostate. Scale bars represent 50 (C) or 100 (A, B, D, E, F) $\mu \mathrm{m}$.

\section{Figure 3}

Immunolocalisation of 17ßHSD14 in A, kidney, B, retina (arrows depicting inner nuclear layer), C stomach, D colon, E rectum and $\mathrm{F}$ duodenum. Peptide neutralisation assay; in $\mathrm{G}$, liver section with17ßHSD14 immunoreactivity and $\mathrm{H}$, liver immunostained with an anti-17ßHSD14 antibody neutralised with a 17ßHSD14-peptide. Scale bars represent 50 (A, B, G, H) or 100 (C, D, E, F) $\mu \mathrm{m}$.

\section{Figure 4}

Interconversion of tritiated steroids in HEK293 (A to D) and MCF10A (E) transiently transfected with HSD17B14 expressed as the fraction of added compound compared to the total amount of added and generated steroid metabolite. Interconversion profiles for HSD17B14-transfected cells compared with that of a mock-transfected cells treated with (A) oestrone, (B) oestradiol, (C) androstenedione, (D) testosterone and (E) dehydroepiandrosterone (DHEA). Representative experiments are shown. Experiments have been performed in duplicates and repeated at least three times.

\section{Table 1}

Summary of immunohistochemical staining patterns and grading of 17ßHSD14 in human tissue 


\section{1 \\ 2 \\ 3}

50

40

30

20

A

$\begin{array}{lll}1 & 2 & 3\end{array}$

50

40

30

20

17ßHSD14

$\beta$-actin

$\beta$-actin

17ßHSD14

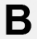




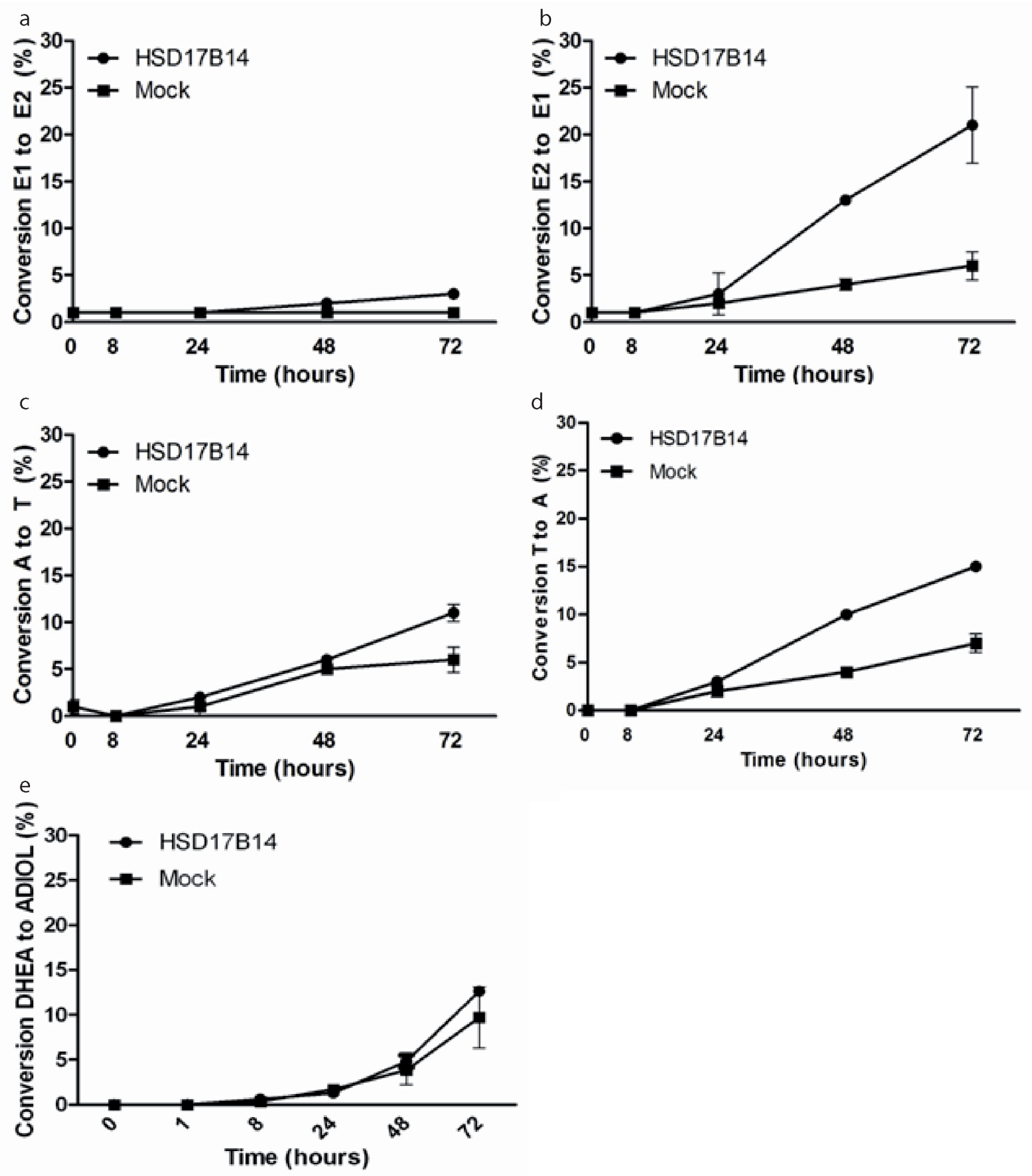


Table 1

\begin{tabular}{l|l|l|l|l} 
Tissue & Female $\boldsymbol{n}$ (median age & Male $\boldsymbol{n}$ (median age) & Grading & Immunolocalisation \\
\hline Adrenal gland & $2(17.5)$ & $1(0,5)$ & Strong & Cortex layer \\
\hline Bone (myeloid) & $5(50)$ & $3(56)$ & moderate & \\
\hline Breast & $60(43.5)$ & & Moderate/strong & Ductal epithelial cells \\
\hline Brain & $14(24)$ & & Moderate & Gray and white matter \\
\hline Colon & $19(54)$ & & Moderate/strong & Glandular surface epithelium \\
\hline Eye & $3(52$ & Strong & Retinal plexiform layers, inner nuclear layer amacrine cells \\
\hline Esophagus & $1(42)$ & & Strong & Mucosal cells \\
\hline Heart & $3(21)$ & $3(22)$ & Strong & \\
\hline Kidney & $5(21)$ & $3(45)$ & Strong & Cortical tubular epithelium \\
\hline Larynx & & $2(35)$ & Moderate & Outer mucosal layer \\
\hline Liver & $6(21)$ & $6(39.5)$ & Strong & Glandular parenchyma \\
\hline Lung & $2(21)$ & Weak & Epithelial cells in bronchial areas \\
\hline Lymph node & $2(38.5)$ & $3(61)$ & Negative & \\
\hline Mesothelium & $2(21)$ & $1(43)$ & Weak & \\
\hline Nerve & $2(18)$ & & Weak & \\
\hline Ovary & $8(21)$ & $2(20.5)$ & Weak & Dominant follicles \\
\hline Pancreas & $6(21)$ & $3(33)$ & Moderate/strong & Acinar cells \\
\hline Parathyroid gland & & $1(56)$ & Moderate/strong & \\
\hline Pituitary & $2(16.5)$ & $60(66)$ & Moderate/strong & \\
\hline Prostate & & $4(50)$ & Weak & Tubuloalveolar epithelium \\
\hline Rectum & $1(35)$ & $2(36)$ & Strong & Gland cell surface epithelium \\
\hline Salivary Gland & $1(38)$ & $3(40)$ & Strong & \\
\hline Skeletal muscle & & $7(35)$ & Strong & \\
\hline Skin & $1(50)$ & $3(40)$ & Moderate & Stratum spinosum and glandular structures \\
\hline Small Intestine & $2(49)$ & $4(32.5)$ & Moderate & Mucosal cells \\
\hline Spleen & $4(21)$ & $5(35)$ & Moderate & \\
\hline Stomach & $3(14)$ & $8(40)$ & Moderate/strong & Glandular \\
\hline Testis & & $6(2)$ & Strong & Spermatogonia, spermatocytes, Leydig cells \\
\hline Thymus gland & $2(18)$ & $2(37.5)$ & Moderate & Centers of Hassals' corpuscles \\
\hline Thyroid & $1(21)$ & $1(48)$ & Weak & \\
\hline Tonsil & $2(21)$ & & Negative & \\
\hline Uterus & $3(21)$ & Moderate/strong & Epithelial cells of endometrial glands
\end{tabular}

